Section Editor

John J. Millichap, MD

Teaching NeuroImages:

\title{
Giant neurocysticercosis with unusual imaging manifestations
}

Dekang Nie, MD*

Liang Xia, MD*

Jian Chen, MD

Wei Shi, MD

Guan Sun, MD

Jun Guo, MD

Correspondence to

Dr. Guo:

ycyyguojun@163.com

or Dr. Sun:

sunguan2008@sina.com

Download teaching slides: Neurology.org

Figure $1 \quad$ Neurocysticercosis images
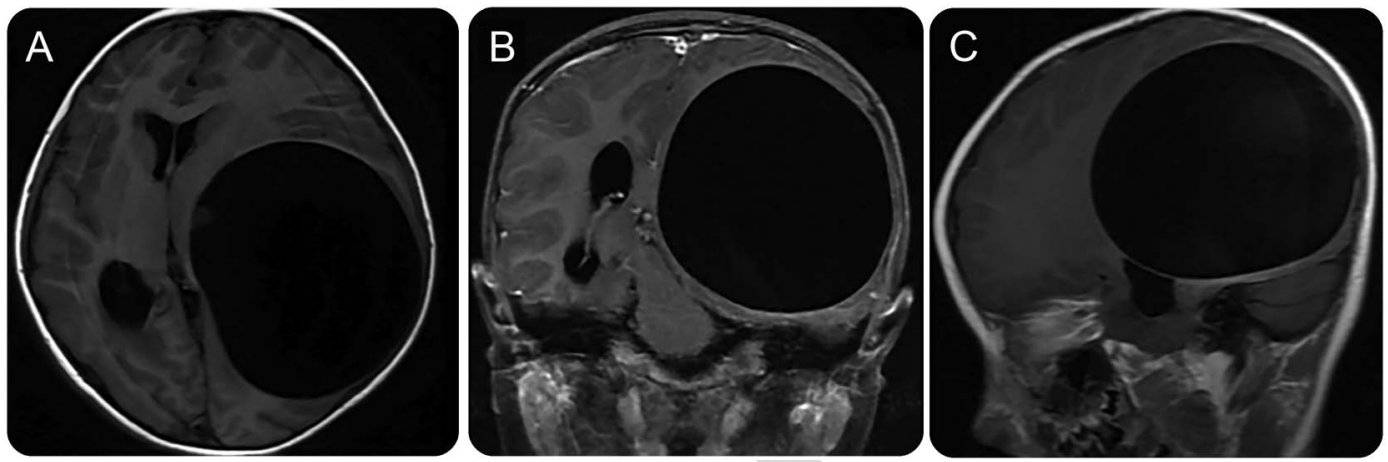

T1-weighted MRI of the spine (A-C) and enhanced MRI (B) demonstrate a single hypointense lesion in the left cerebral hemisphere with no perilesional edema and contrast enhancement.

A 6-year-old girl presented with a 3-month history of resection and then was given antihelminthic therapy. progressive left-eye strabismus and vision loss. MRI This resulted in an uneventful recovery. Pathology scan of the brain showed a single hypointense lesion confirmed a diagnosis of cysticercus cyst with scolex. in the left cerebral hemisphere with no perilesional This imaging feature of giant neurocysticercosis is edema or contrast enhancement (figure 1, A-C). At surgery, the lesion was shown to be a single large parasitic cyst measuring approximately $7.0 \times 6.5 \times 6.0 \mathrm{~cm}$ (figure 2, A-C). The patient underwent a complete very unusual. ${ }^{1}$ In the event of neurologic dysfunction or elevated intracranial pressure, emergent operative intervention should precede the administration of antihelminthic medications as the latter may weaken

Figure 2 Imaging of surgical specimens and histopathology
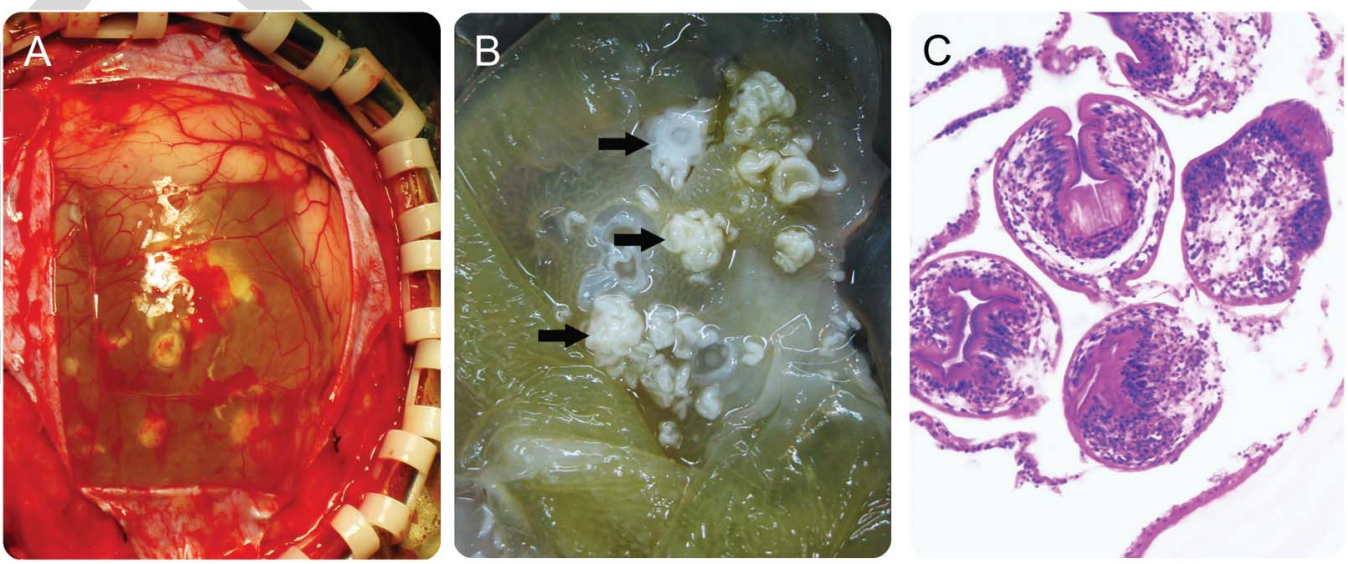

Surgical area (A) and resection specimens (B) show a white floc floating in the cystic fluid (black arrows); thick cyst wall exhibits milkiness. Pathology confirmed a diagnosis of cysticercus cyst with scolex (C).

*These authors contributed equally to this work.

From the Department of Neurosurgery (D.N., G.S., J.G.), Fourth Affiliated Hospital of Nantong University, Yancheng; Department of Neurosurgery (L.X.), Zhejiang Cancer Hospital, Hangzhou; and Department of Neurosurgery (J.C., W.S.), Affiliated Hospital of Nantong University, Nantong, China.

Go to Neurology.org for full disclosures. Funding information and disclosures deemed relevant by the authors, if any, are provided at the end of the article. 
the cyst membrane and complicate resection. Gross total resection has advantages compared with nonsurgical treatment with antihelminthics. ${ }^{2}$

\section{AUTHOR CONTRIBUTIONS}

Dekang Nie: drafting/revising the manuscript, study concept or design. Jun Guo: study concept or design and study supervision. Liang Xia: analysis or acquisition of data. Jian Chen: revising the manuscript. Wei Shi: analysis or interpretation of the data. Guan Sun: analysis and interpretation of data.

\section{ACKNOWLEDGMENT}

The authors thank staff of the Department of Neurosurgery of the Affiliated Hospital of Nantong University for technical assistance and equipment support.

\section{STUDY FUNDING}

No targeted funding reported.

\section{DISCLOSURE}

The authors report no disclosures relevant to the manuscript. Go to Neurology.org for full disclosures.

\section{REFERENCES}

1. Nash TE, Del Brutto OH, Butman JA, Corona T, DelgadoEscueta A. Calcific neurocysticercosis and epileptogenesis. Neurology 2004;62:1934-1938.

2. Takeshita I, Li HZ, Imamoto N, Cao YP, Gou CF. Unusual manifestation of cerebral cysticercosis [in Japanese]. Fukuoka Igaku Zasshi 1994;85:29-34. 


\section{Neurology}

Teaching NeuroImages: Giant neurocysticercosis with unusual imaging manifestations: [RETRACTED]

Dekang Nie, Liang Xia, Jian Chen, et al.

Neurology 2016;87; e260-e261

DOI 10.1212/WNL.0000000000003356

This information is current as of November 21, 2016

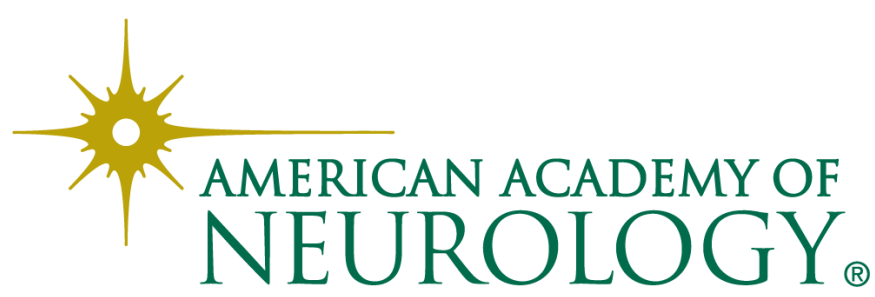




\section{Updated Information \& Services}

\section{Supplementary Material}

References

Citations

Subspecialty Collections

Errata

Permissions \& Licensing

\section{Reprints}

including high resolution figures, can be found at: http://n.neurology.org/content/87/21/e260.full

Supplementary material can be found at: http://n.neurology.org/content/suppl/2016/11/21/WNL.0000000000003 356.DC1

This article cites 2 articles, 1 of which you can access for free at: http://n.neurology.org/content/87/21/e260.full\#ref-list-1

This article has been cited by 3 HighWire-hosted articles: http://n.neurology.org/content/87/21/e260.full\#\#otherarticles

This article, along with others on similar topics, appears in the following collection(s):

\section{Central pain}

http://n.neurology.org/cgi/collection/central_pain

Medical care

http://n.neurology.org/cgi/collection/medical_care

\section{MRI}

http://n.neurology.org/cgi/collection/mri

Parasitic infections

http://n.neurology.org/cgi/collection/parasitic_infections

Post-infectious

http://n.neurology.org/cgi/collection/postinfectious_

An erratum has been published regarding this article. Please see next page or:

/content/88/23/2239.2.full.pdf

Information about reproducing this article in parts (figures,tables) or in its entirety can be found online at:

http://www.neurology.org/about/about_the_journal\#permissions

Information about ordering reprints can be found online:

http://n.neurology.org/subscribers/advertise

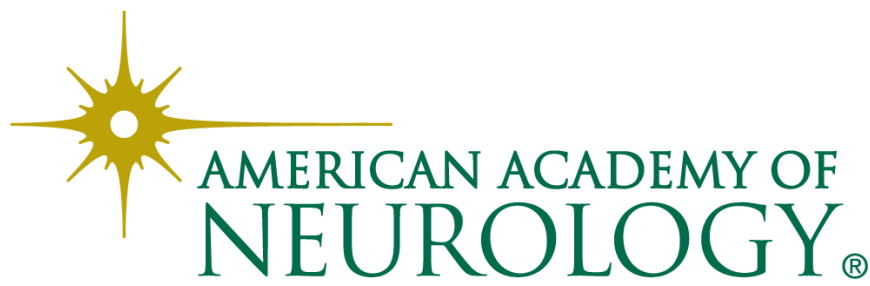


1. Wasilewski A, Samkoff L. Teaching NeuroImages: Idiopathic hypertrophic pachymeningitis. Neurology 2016;87: e270-e271.

2. De Virgilio A, de Vincentiis M, Inghilleri M, et al. Idiopathic hypertrophic pachymeningitis: an autoimmune IgG4-related disease. Immunol Res Epub 2016 Sep 3.

3. Della-Torre E, Galli L, Franciotta D, et al. Diagnostic value of IgG4 indices in IgG4-related hypertrophic pachymeningitis. J Neuroimmunol 2014;266:82-86.

4. Lindstrom KM, Cousar JB, Lopes MB. IgG4-related meningeal disease: clinico-pathological features and proposal for diagnostic criteria. Acta Neuropathol 2010;120:765-776.

5. Liao B, Kamiya-Matsuoka C, Fang X, Smith RG. Refractory IgG4-related intracranial hypertrophic pachymeningitis responded to rituximab. Neurol Neuroimmunol Neuroinflamm 2014;1:e41.

(C) 2017 American Academy of Neurology

AUTHOR RESPONSE: TEACHING NEUROIMAGES: IDIOPATHIC HYPERTROPHIC PACHYMENINGITIS

Andrea Wasilewski, Lawrence Samkoff, Rochester,

NY: As discussed by Dr. Budhram, immunoglobulin G4 (IgG4)-related disease (RD) must be considered in patients with hypertrophic pachymeningitis (HP) as it accounts for a high proportion of cases originally thought to be idiopathic. ${ }^{1}$ IgG4-related HP is pathologically characterized by a lymphoplasmacytic infiltration of IgG4-positive plasma cells. ${ }^{2}$ The patient we presented had normal IgG4 levels in both serum and CSF. ${ }^{1}$ Dural biopsy was consistent with a chronic lymphohistiocytic pachymeningitis without substantial plasma cell infiltrate to suggest IgG4-RD. In addition, immunohistochemistry performed on the dural biopsy specimen was IgG4-negative. Our case highlights the steroid responsiveness of idiopathic $\mathrm{HP}$ and the excellent response to immunotherapy with methotrexate. ${ }^{1}$ We agree with Dr. Budhram that immunostaining of dural specimens should be done in patients with HP, as this may help guide treatment for steroid-refractory HP when IgG4 disease can be identified.

1. Wasilewski A, Samkoff L. Teaching NeuroImages: Idiopathic hypertrophic pachymeningitis. Neurology 2016;87: e270-e271.

2. Lu LX, Della-Torre E, Stone JH, Clark SW. IgG4-related hypertrophic pachymeningitis: clinical features, diagnostic criteria, and treatment. JAMA Neurol 2014;71:785-793.

(C) 2017 American Academy of Neurology

\section{RETRACTION}

Teaching NeuroImages: Giant neurocysticercosis with unusual imaging manifestations

The Neurology ${ }^{\circledR}$ editors and the authors of the article "Teaching NeuroImages: Giant neurocysticercosis with unusual imaging manifestations," ${ }^{1}$ published online in conjunction with the November 22, 2016, issue of Neurology, agree to the retraction of the article. Retraction follows publication of a WriteClick ${ }^{\circledR}$ Editor's Choice correspondence exchange in which a pervasive translation error was identified. ${ }^{2,3}$ The diagnosis should have been "cystic echinococcosis," not "cysticercus." The article has been corrected and republished. ${ }^{4}$

\section{REFERENCES}

1. Nie D, Xia L, Chen J, et al. Teaching NeuroImages: Giant neurocysticercosis with unusual imaging manifestations. Neurology 2016;87:e260-e261.

2. Del Brutto OH. Letter: Teaching NeuroImages: Giant neurocysticercosis with unusual imaging manifestations. Neurology 2017;88:2238.

3. Guo J. Author response: Teaching NeuroImages: Giant neurocysticercosis with unusual imaging manifestations. Neurology 2017;88:2238.

4. Nie D, Xia L, Chen J, et al. Teaching NeuroImages: Giant cystic echinococcosis with unusual imaging manifestations. Neurology 2017;88:e234-e235. 